\title{
РЕЗУЛЬТАТИ ДОСЛІДЖЕННЯ ПСИХОЛОГІЧНОГО СТАНУ УЧАСНИКІВ ОСВІТНЬОГО ПРОЦЕСУ В УМОВАХ ПАНДЕМІї COVID-19
}

https://doi.org/10.37472/2707-305X-2021-3-1-9-1

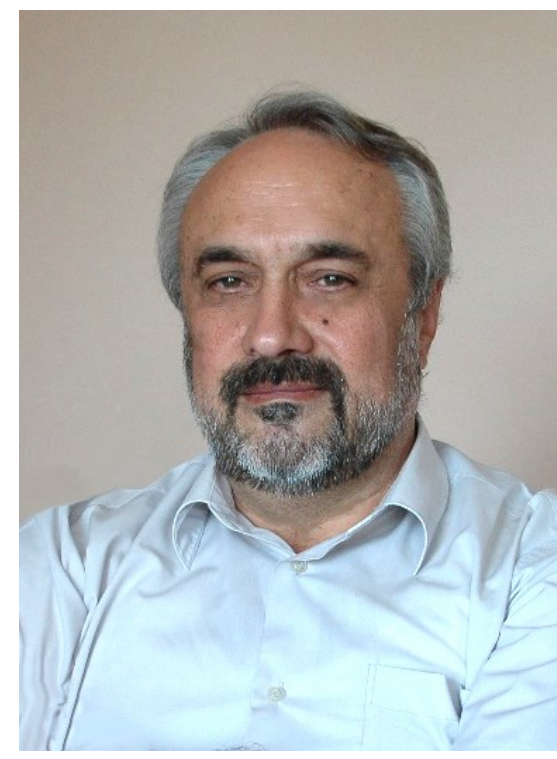

ПАНОК Віталій Григорович доктор психологічних наук, професор, член-кореспондент НАПН України, директор Українського науковометодичного чентру практичної психології $і$ сочіальної роботи, Національна академія педагогічних наук України, м. Київ, Україна

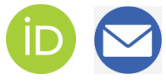

Анотація. Пандемія COVID-19 торкнулася усіх сфер життя, зокрема і системи освіти. Педагоги, учні, їхні батьки опинилися у складній і незвичайній для себе ситуації як у професійній сфрері, так і в особистому житті. Визначення соціально-психологічних наслідків впливу пандемії на учасників освітнього прочесу стало предметом дослідження. У листопаді минулого року проведено всеукраїнське опитування педагогів, метою якого було визначення впливу пандемії і карантинних заходів на здійснення освітнього процесу загалом $i$ його учасників зокрема. У цій статті наводяться результати всеукраїнського опитування з виявлення найбільш актуальних соціально-психологічних проблем в освітньому прочесі в умовах пандемії.

Ключові слова: пандемія COVID-19; соціально-психологічні наслідки; учасники освітнього процесу; емпіричне дослідження; емоційний стан; інформованість; дистанційне навчання; негативні емоційні стани.

Актуальність. Починаючи з другої декади 2020 р., коли Всесвітня організація охорони здоров'я (ВООЗ) офіційно оголосила пандемію вірусу COVID-19, фактично увесь світ перейшов у стан надзвичайної ситуації. Боротьба з новим вірусом ускладнюється й тим, що інформація про нього часто $є$ суперечливою та викликає недовіру, оскільки засоби масової інформації спираються на різні джерела й не тільки офіційні. Генеральний директор ВООЗ Тедрос Адхан Гебрейєсус (Tedros Adhanom Ghebreyesus) увів новий термін сучасної реальності - «інфодемія», що означає інфікування надмірною та неперевіреною інформацією, відсутність критичного мислення при сприйнятті нової (Суспільне. Новини. 2020). Брак належної збалансованої інформації щодо COVID-19 спричиняє паніку з серйозними згубними наслідками для життєдіяльності, соціального життя, економіки та політичної стабільності.

За заявою ООН, пандемія коронавірусу може спровокувати кризу психічного здоров'я. Негативними наслідками під час виникнення у всьому світі такої екстремальної ситуації, як пандемія невідомого вірусу, з котрим ще не стикалось людство, є паніка, немотивована агресія, страх, що безпосередньо позначаються на поведінці, а саме: зростання дій, спрямованих на біологічне самозбереження; зменшення проявів альтруїстичної поведінки; обмеження соціальних контактів, що призводить до виникнення смутку, розчарування та відчуття ізоляції, депривації тощо.

«Проблеми психічного здоров'я, зокрема депресія і тривожність, є однією з найбільших причин нещасть у нашому світі. Після десятиліть занедбаності й недостатнього інвестування в послуги з психічного здоров'я, пандемія COVID-19 зараз вражає сім'ї і громади $з$ додатковим психічним стресом», - заявив Генеральний 
секретар ООH Антоніо Ґутерріш (António Manuel de Oliveira Guterres) (Радіо Свобода, 2020).

Існують й інші серйозні соціально-психологічні проблеми, з якими через пандемію вже стикаються психологи та фахівці різних галузей. Десятки мільйонів людей у всьому світі вже відчули економічне потрясіння унаслідок втрати роботи, зменшення доходів і засобів до існування через карантин. ООН застерігає, що вплив економічного стресу може призвести до «смертей від відчаю» - самогубств.

За статистикою звернень до гарячих ліній і телефонів довіри значно збільшилась кількість звернень з проблемою домашнього насильства, жорстокого поводження через самоізоляцію. Більше за все від домашнього насильства страждають діти, підлітки та літні люди (Перший український інформаційний телеканал «5 канал», 2020).

Психологічні наслідки від пандемії не так яскраво виражені, проте матимуть довготривалий влив і позначатимуться не тільки на психоемоційному, а й на психосоціальному та інтелектуальному розвиткові (Панок, 2020; Furman, et al., 2020). Вже зараз підлітки та молодь потерпають від перерви у навчанні, соціальної депривації, відчувають невпевненість у майбутньому та невизначеність щодо подальшого професійного шляху. Стреси та конфлікти у сім'ях також не можуть не впливати на психофізичний і психоемоційний розвиток дітей (Кремень, 2020).

Психологічна служба системи освіти, відповідно до Закону України «Про освіту» (ст. 76) (Закон України, 2017), має забезпечувати психологічний супровід і соціально-педагогічний патронаж усіх учасників освітнього процесу (МОН України, 2019). Тому одним із пріоритетів діяльності психологічної служби в сучасних умовах $є$ подолання соціально-психологічних наслідків пандемії у закладах освіти засобами прикладної психології і соціальної педагогіки.

Першорядними завданням психологічної науки для закладів освіти сьогодні $€$ вивчення соціально-психологічних наслідків пандемії і пов'язаних з нею соціальних явищ для оптимізації освітнього процесу (Панок, Марухіна \& Романовська, 2020).

Організація і методологія дослідження. Для визначення пріоритетних заходів у подоланні негативних впливів пандемії протягом 1926 листопада 2020 р. вчені Українського науковометодичного центру практичної психології і соціальної роботи провели всеукраїнське онлайн- опитування педагогічних працівників закладів загальної середньої освіти щодо наслідків пандемії COVID-19. Дослідження відбувалось у рамках виконання наукової теми «Подолання наслідків пандемії COVID-19 у діяльності психологічної служби системи освіти» на замовлення Національного фонду досліджень України (реєстраційний номер проєкту - 2020.01/0114).

Мета анкетування - визначення впливу пандемії і карантинних заходів на здійснення освітнього процесу загалом і його учасників зокрема. Опитування анонімне, рівень - всеукраїнський. Анкета «Виявлення соціальнопсихологічних проблем, породжених пандемією COVID-19 у діяльності закладів освіти» (автор В.Г. Панок) поширювалась через google-сервіси та соціальні мережі. В опитуванні взяло участь 3209 педагогічних працівників закладів загальної середньої освіти з усіх регіонів України, $45 \%-3$ міст, 55 \% - сільської місцевості, 92 \% жінок, 8 \% чоловіків.

Виклад основного матеріалу. Узагальнення результатів опитування педагогічних працівників щодо їх оцінки впливу пандемії COVID-19 на учасників освітнього процесу в закладах загальної середньої освіти дало змогу вченим одержати таку інформацію.

Серед джерел інформації про шляхи передачі та профілактику інфікування COVID-19 найбільшу довіру в педагогічних працівників викликають соціальні мережі - 65,3\%, водночас рівень недовіри до них становить 16,9\%. Офіційні джерела інформації (розпорядження, бюлетені центральної і місцевої влади) посіли друге місце (64,6 \%). При цьому повністю їм довіряють майже $21 \%$ опитаних. Неофіційним джерелам (друзі, знайомі) висловили довіру 51,9\% опитаних. Телебаченню загалом довіряють 50,2%, з них 10,2 \% респондентів довіряють повністю. Повністю або частково не довіряють телебаченню 31,4 \% опитаних.

Самооцінка рівня інформованості учасників освітнього процесу про шляхи передачі та профілактику інфікування COVID-19 є доволі високою: 94,6 \% - педагогічні працівники, 88,3\% - учні (за оцінкою педагогів), 86,8\% - батьки (за оцінкою педагогів).

Труднощі й страхи педагогічних працівників, викликані пандемією, розділились за ступенем значущості так:

«Боюсь заразитись і захворіти на COVID-19 (заразити членів сім'ї)» - 78,2\%. При цьому 
максимальну оцінку (10 балів) поставили 40,9 \% від усіх опитаних, лише 9,3 \% заявили, що їм такі страхи не притаманні.

Проблеми, пов'язані з використанням IKT (відсутність компетентностей) - 53,2 \% респондентів, з яких 22,2 \% мають значні труднощі, $31 \%$ - незначні, а 15,7\% опитаних вважають себе повністю компетентними.

Про труднощі із залученням дітей до дистанційних занять зазначили 73 \% педагогів (12,8 \% вважають їх максимальним балом).

«Важко дотримуватись всіх протиепідемічних вимог у закладі освіти для того, щоб захистити учнів» - 69,5 \% учасників опитування заявили, що саме це викликало ускладнення у професійній діяльності.

Труднощі з розподілом часу (робота, відпочинок, сімейні справи, власні діти) - 60,7 \% респондентів відповіли, що це для них $є$ істотною проблемою, при цьому майже 18 \% оцінили її найвищим балом.

Неможливість виконання у повному обсязі запланованих завдань і професійних обов'язків позитивно відповіли 59,6\% опитаних, з них максимальний бал зазначили 12,3 \%.

Емоційне виснаження, зниження рівня емоційної рівноваги, надмірну втому - 58,7\% педагогічних працівників підтвердили цю проблему як істотну, з них майже 18 \% - як дуже істотну.

Зниження навчальної мотивації учнів помітили $58,1 \%$ респондентів, 3 них 13,5\% оцінили цю проблему максимально.

Порушення комунікації з батьками щодо контролю за якістю знань учнів констатували 51,1 \% педагогів, з них 8,7 \% - позначили максимальною оцінкою.

Щодо труднощів 3 дисципліною учнів на уроках, - 47,9\% опитаних стверджують, що мають ускладнення з дисципліною учнів.

Труднощі, пов'язані з власним здоров'ям (хворію чи перехворів/ла на COVID-19 та здоров'я ще не відновилось): 31,2\% педагогів вважають цю проблему актуальною для себе та 8,9\% оцінили ії як дуже актуальну. Натомість 30,4 \% опитаних заперечили для себе існування такої проблеми.

Оцінка педагогами ступеня актуальності проблем здобувачів освіти, пов'язаних із пандемією (за значущістю).

Хвилювання старшокласників щодо складання ЗНО респонденти оцінили так: 59,1 \% - високий, 26,1 \% - середній, 14,8 \% - низький рівні.
Невміння організувати свій час (навчання, відпочинок), відсутність самоконтролю: 52 \% високий, $32 \%$ - середній, $16 \%$ - низький рівні.

Зниження рівня знань і когнітивних функцій як актуальну проблему назвали 46,5\% опитаних, 36,7 \% вважають її помітною, 16,8 \% - незначною.

Порушення комунікації з однокласниками та іншими учнями в школі: 44,3\% - високий, $33 \%$ - середній, 22,7\% - низький рівні.

Зниження рівня дисципліни здобувачів освіти: $37 \%$ вважать, що пандемія істотно вплинула на дисципліну учнів; 35,4 \% визнають деякий вплив 27,6 \% вважають, що на дисципліну учнів карантинні заходи сильно не вплинули.

На думку педагогів, боязнь заразитись і захворіти на COVID-19 (заразити членів сім'ї) притаманна учням: 33,4\% - високий рівень страху, 36,6 \% - середній, 29,9\% - низький. Отже, страхи зараження в учнів виражені приблизно порівну.

Педагоги оцінили ступінь актуальності проблем батьків учнів, пов'язаних із пандемією (за ступенем значущості):

- Невміння батьками організовувати дітей вдома під час дистанційного навчання (навчання, відпочинок) відзначили 72,3 \% респондентів.

- Батьки бояться заразитись і захворіти на COVID-19 чи заразити членів сім'ї - 71,1\% опитаних.

- Батьки відчувають роздратування, знервованість, агресію - про це заявили більше половини респондентів, а саме 64,7\%.

Щодо труднощів батьків, пов'язаних з їхнім станом здоров'я чи станом здоров'я інших членів сім'ї (хворіють чи не повністю відновились після перенесеної хвороби), думки педагогів розділи лись: 47,5 \% - підтверджують певні труднощі у батьків, 45,9 \% - заявили, що батьки не мають труднощів.

Аналіз даних свідчить, що сьогодні спостерігається тенденція до посилення емоційного напруження учасників освітнього процесу, що спричи нено невмінням критично сприймати інформацію про особливості перебігу пандемії та ії наслідків. Зазначимо, що нині є багато невідпрацьованих питань щодо організації навчання у дистанційних умовах, комунікації у колективах, можливостей забезпечення психологічного супроводу усіх учасників освітнього процесу.

Емоційний стан учасників освітнього процесу може бути охарактеризований як такий, де переважають негативні емоції і настрої - триво- 
га, страх, роздратування, агресія тощо. У багатьох $€$ ознаки емоційного вигорання, астенічні реакції, симптоми дистресу.

Педагоги оцінили свій настрій до пандемії і натепер:

- емоційний підйом різного ступеня «до» 68,3 \% «тепер»- 30 \%;

- емоційний спокій, врівноваженість «до» $16 \%$, «тепер» - $32 \%$;

- пригнічені стани різного ступеня «до» 14,6 \%, «тепер» - 35,4\%.

Педагоги оцінили емоційний стан учнів до пандемії і натепер:

- емоційний підйом різного ступеня «до» 80,4 \% «тепер» - 40,9 \%;

- емоційний спокій, врівноваженість «до» 9,2 \%, «тепер»- 30,6 \%;

- пригнічені стани різного ступеня прояву «до» - 9 \%, «тепер» - 26,5\%.

Одержані результати можуть бути підставою для пошуку чи розроблення методів психологічної профілактики емоційного вигорання, корекції негативних емоційних станів, страхів, настроїв учасників освітнього процесу.

Одним із завдань дослідження було з'ясувати, наскільки толерантно ставляться опитувані до людей (дітей), які хворіють або перехворіли на COVID-19. Для цього було сформульовано кілька запитань до педагогічних працівників закладів загальної середньої освіти. Наприклад: «Чи треба ізолювати від суспільства людей, які перехворіли на COVID-19?» Підтримали думку про ізоляцію таких людей лише 4,6\% опитаних; решта 95,4\% відповіли негативно.

Для визначення соціальної ізоляції (дистанціювання) респондентам було поставлено запитання: «Чи знаєте Ви випадки, коли діти / люди, які перехворіли на COVID-19, потрапляють у соціальну ізоляцію - з ними не хочуть спілкуватися, їсти в одному приміщенні, сидіти за одним столом / партою?».Відповіді респондентів розподілились у такому співвідношенні: «Так, мені відомі такі випадки» - 17,6\%, «Ні» $82,4 \%$.

Отже, COVID-дискримінація, на думку опитаних, поширена в нашому суспільстві майже на $18 \%$. Часто така дискримінація призводить до конфліктів, суперечок, образ, психологічного і фізичного насильства.

«Чи знаєте Ви випадки COVID-булінгу (цькування, ображання) людей, хворих (або тих, які перехворіли) на COVID-19 серед Ваших знайо- мих, учнів, батьків, колег?» (0 - такого не знаю; 1 - вкрай мало, 10 - дуже багато). На це запитання були одержані такі відповіді: «Такого не знаю» - 58,6\%, загалом знають про такі випадки $41,4 \%$.

Одержані дані переконливо свідчать про необхідність проведення роз'яснювальної роботи серед учнів і педагогів щодо профілактики випадків COVID-булінгу, формування толерантного ставлення до хворих або тих, хто перехворів, формування доброзичливих, співчутливих взаємин у колективах, організації взаємодопомоги та доброчинності у закладах освіти.

Для організації психологічної допомоги учасникам освітнього процесу важливо було з'ясувати, як респонденти бачать свої життєві перспекти ви, наскільки оптимістичним вважають своє майбутнє, вірять у власні сили і володіють життє стійкістю / стресостійкістю (resilience).

Учасникам запропоновано запитання: «Як скоро, на Вашу думку, закінчаться проблеми 3 COVID-19?». Варіантів відповідей було шість. Вибрати можна було тільки один, що відображає думку / оцінку респондента. Одержано такі відповіді:

- дуже скоро, все знову буде добре, всі будуть радісні й веселі - 4,2 \%;

- скоро, все буде добре - 16,4 \%;

- усе це просто так не минеться - $14 \%$;

- ще не скоро, ми багато втратимо - 22,7\%;

- ніколи, вже так добре, як було, не буде ніколи - 9,7\%;

- важко відповісти - 33 \%.

Отже, загалом оптимістично дивляться у майбутнє лише 20,6 \% опитаних, «обережних песимістів» - 14\%, явних песимістів - 32,4\%. При чому 9,7\% від усіх опитаних перебувають у депресивному стані. Звертає на себе увагу найбільша кількість респондентів, які не змогли дати конкретну відповідь. Так, більше третини опитаних потребують термінової психологічної допомоги і ще приблизно стільки ж - корегування свого ставлення до пандемії та ї̈ наслідків для особистого життя і професійної діяльності.

Висновки та рекомендації.

1. Результати дослідження показали, що в суспільстві актуальним є запит на одержання достовірної інформації про шляхи зараження COVID-19, засоби профілактики захворювання, способи спілкування з людьми, які інфіковані або перехворіли, заходи, що вживаються центральною і місцевими органами виконавчої влади 
щодо запобігання поширенню пандемії. У зв'язку з цим необхідно провести скоординовану державну інформаційно-просвітницьку компанію із залученням представників центральної і місцевої влади, вчених, лікарів-інфекціоністів, авторитетних представників громадянського суспільства та інших фахівців. Засобами донесення об'єктивної інформації мають бути: офіційні повідомлення через інформаційні бюлетені, листи, розпорядження, які доводяться до керівників і трудових колективів, установ і закладів освіти; соціальні мережі, у яких публікується офіційна інформація (листи, розпорядження, статистика); центральне і місцеве телебачення.

2. У рамках державно-громадського співробітництва потрібно залучати на всеукраїнському і місцевому рівнях до роботи соціальних служб та органів піклування і опіки громадські та благодійні організації для надання допомоги інфікованим і тим, хто перехворів на COVID-19, а також літнім людям, особам з інвалідністю, дітям і сім'ям, що виховують дітей з особливими освітніми потребами, малозабезпеченим сім'ям та родинам, що проживають у сільській (гірській) місцевості.

3. Через систему післядипломної освіти усіх міністерств (насамперед, інститути післядипломної педагогічної освіти) необхідно налагодити впровадження курсів (спецкурсів), лекцій, семінарів, тренінгів із проблем запобігання захворюванню на COVID-19, забезпечення регламентів роботи в умовах пандемії на робочих місцях, дотримання карантинних заходів, надання першої домедичної допомоги, процедур вакцинування. Потрібно долучити до цієї роботи найкращих вітчизняних фахівців, епідеміологів, інфекціоністів, фахівців із соціальної роботи і соціальної педагогіки, практичних психологів.

4. Для забезпечення якісного дистанційного навчання у закладах загальної середньої освіти рекомендується: забезпечити заклади освіти надійним інтернет-зв'язком; провести курси підвищення кваліфікації для педагогів з метою формування стійких компетенцій IT-користувача; провести курси тайм-менеджменту в умовах дистанційного навчання; організувати групи подовженого дня для дітей із малозабезпечених сімей, дітей з місцевостей, де немає надійного інтернет-зв'язку.

5. Соціальним педагогам закладів освіти доцільно внести зміни у річні плани роботи, доповнивши їх питаннями: проведення роз'яснювальної роботи з педагогічним колективом щодо перебігу пандемії, засобів захисту від передачі інфекції у закладі освіти при роботі з дітьми, організації роботи в умовах дистанційного навчання (тайм-менеджмент), організації у закладі освіти груп допомоги і самодопомоги серед учнів, батьків і педагогічних працівників, надання соціально-педагогічної допомоги дітям і сім'ям, які перебувають у складній життєвій ситуації, дітям з особливими освітніми потребами, літнім та одиноким людям.

6. Практичним психологам закладів освіти важливо внести зміни у річні плани роботи, доповнивши їх такими питаннями: профілактика серед вчителів і учнів COVID-булінгу, дискримінації і стигматизації інфікованих, або тих, хто перехворів на COVID-19. Основну увагу варто зосередити на роботі з негативними емоційними станами учасників освітнього процесу та підвищенні стресостійкості педагогів і учнів, профілактиці конфліктів, формуванні позитивних життєвих перспектив, роботі з депресивними станами.

Підбиваючи підсумки, потрібно наголосити на необхідності подальшого дослідження соціальнопсихологічних проблем пандемії у системі освіти 3 метою виявлення найбільш гострих проблем учасників освітнього процесу - вчителів, учнів і їхніх батьків, та визначення тенденцій подальшого їх розвитку. Отримані результати стануть науковим підґрунтям в організації ефективної соціально-педагогічної і психологічної допомоги, розробці курсів для системи післядипломної педагогічної освіти, створенні нових методик і технологій корекційно-розвиткової роботи, що врешті зможе підвищити якість освіти.

\section{Автори-учасники проєкту:}

В.Г.Панок - доктор психологічних наук, професор, член-кореспондент НАПН України, науковий керівник, директор Центру;

I.І. Ткачук - кандидат педагогічних наук, завідувач лабораторії прикладної психології освіти;

Д.Д. Романовська - кандидат психологічних наук, старший науковий співробітник;

Р.А. Мороз - кандидат психологічних наук, старший науковий співробітник;

Т.Б. Гніда - кандидат психологічних наук, старший науковий співробітник;

Т.Д. Каменшук - кандидат психологічних наук, старший науковий співробітник;

Н.В. Сосновенко - науковий співробітник;

В.М. Горленко - науковий співробітник.

Авторські права застережено. 


\section{СПИСОК ВИКОРИСТАНИХ ДЖЕРЕЛ}

Закон України «Про освіту». (2017, 5 вересня). https:// zakon.rada.gov.ua/laws/show/2145-19

Кремень, В.Г. (ред.). (2020). Психологія і педагогіка у протидії пандемії COVID-19 : інтернет-посібник. Київ: ТОВ «Юрка Любченка». https:// lib.iitta.gov.ua/719827/

Міністерство освіти і науки України. (2019, 18 липня). Про пріоритетні напрями роботи психологічноі служби у системі освіти на 2019-2020 н.р. (1/9462). https://bit.ly/3pKSeK7

Панок, В.Г. (2020). Психологічний супровід реформування освіти. In Т.О. Олефіренко, ред. Психологічний $i$ педагогічний дискурс: наукові записки вчених : збірник матеріалів конференції (с. 12-15). Київ: Видавництво НПУ імені М.П. Драгоманова.

Панок, В.Г., Марухіна, І.В., \& Романовська, Д.Д. (2020). Психологічний супровід освіти в умовах пандемії. Вісник Національної академії педагогічних наук
України, 2(2). https://doi.org/10.37472/2707-305X2020-2-2-12-2

Перший український інформаційний телеканал «5 канал». (2020, 6 травня). Домашнє насильство nid час карантину. https://bit.ly/3bC13AW

Радіо Свобода. (2020, 14 травня). ООН: пандемія коронавірусу може призвести до кризи психічного здоров'я у свіmi. https://www.radiosvoboda.org/a/ news-oon-psykhichne-zdorovya/30611282.html

Суспільне. Новини. (2020, 19 березня). Світові інтелектуали про наслідки пандемії коронавірусу для людства. https://suspilne.media/20654-svitoviintelektuali-pro-naslidki-pandemii-koronavirusudlaludstva/

Furman, O., Shandruk, S., Gerasymova, E., Panok, V., Vasylkiv, O., \& Lukashuk, M. (2020). Psychological and educational support of students' self-regulation development. International Journal of Management, 11(4), 326338. https://doi.org/10.34218/IJM.11.4.2020.033

\section{RESULTS OF A STUDY ON THE PSYCHOLOGICAL STATE OF THE EDUCATIONAL PROCESS PARTICIPANTS UNDER THE COVID-19 PANDEMIC}

\section{Vitalii Panok}

DSc in Psychology, Professor, Corresponding Member of NAES of Ukraine, Director, Ukrainian Scientific and Methodological Center of Applied Psychology and Social Work, National Academy of Educational Sciences of Ukraine, Kyiv, Ukraine

Abstract. The COVID-19 pandemic has affected all spheres of life including education. The educational process participants - teachers, pupils, and their parents - find themselves in an unusual and challenging situation, both in professional and private life. Determining the pandemic's socio-psychological consequences on participants in the educational process was the subject of the study. In November 2020 an all-Ukrainian survey of teachers was conducted to determine the impact of the pandemic and quarantine measures on the educational process in general and its participants in particular. The following paper reveals the results of a nationwide survey to identify the most pressing social and psychological issues in the educational process under the pandemic context.

Keywords: COVID-19 pandemic; socio-psychological consequences; educational process participants; empirical research; emotional state; awareness; distance learning; negative emotional states. 